\title{
Biotransformation of caffeoyl quinic acids from green coffee extracts by Lactobacillus johnsonii NCC 533
}

\author{
Rachid Bel-Rhlid" ${ }^{*}$, Dinesh Thapa ${ }^{2}$, Karin Kraehenbuehl ${ }^{1}$, Carl Erik Hansen ${ }^{1}$ and Lutz Fischer ${ }^{3}$
}

\begin{abstract}
The potential of Lactobacillus johnsonii NCC 533 to metabolize chlorogenic acids from green coffee extract was investigated. Two enzymes, an esterase and a hydroxycinnamate decarboxylase (HCD), were involved in this biotransformation. The complete hydrolysis of 5-caffeoylquinic acid (5-CQA) into caffeic acid (CA) by L. johnsonii esterase occurred during the first $16 \mathrm{~h}$ of reaction time. No dihydrocaffeic acid was identified in the reaction mixture. The decarboxylation of CA into 4-vinylcatechol (4-VC) started only when the maximum concentration of CA was reached $(10 \mu \mathrm{mol} / \mathrm{ml})$. CA was completely transformed into $4-\mathrm{VC}$ after $48 \mathrm{~h}$ of incubation. No 4-vinylphenol or other derivatives could be identified in the reaction media. In this study we demonstrate the capability of $L$. johnsonii to transform chlorogenic acids from green coffee extract into 4-VC in two steps one pot reaction. Thus, the enzymatic potential of certain lactobacilli might be explored to generate flavor compounds from plant polyphenols.
\end{abstract}

Keywords: Chlorogenic acid, 4-vinylcatechol, Esterase, Decarboxylase, L. johnsonii

\section{Introduction}

Polyphenols have been reported to exert a variety of biological activities, such as free radical scavenging, metal chelating and modulation of enzyme activity (Sud'ina 1993). The main classes of phenolic compounds are hydroxycinnamic acids such as caffeic acid (CA), ferulic acid (FA), and $p$-coumaric acid (PCA), mainly in esterified form with organic acids, sugars, and lipids. CA (Figure 1) is the major representative of hydroxycinnamic acids and occurs in foods essentially as ester with quinic acid (chlorogenic acids) (Figure 1). Although chlorogenic acids are common in vegetables, the largest amounts are present in coffee (Clarke 1987). These phenolic acids are toxic to some but not all microorganisms. Some Pseudomonas strains, as well as Acinetobacter calcoaceticus, are able to use them as the sole source of carbon for growth (Overhage 1999). Other studies have confirmed the ability of some lactic acid bacteria to metabolize $p$-coumaric acid into 4-vinylphenol (4-VP) (Osborn 1997). One of the

\footnotetext{
*Correspondence: rachid.bel-rhlid@rdls.nestle.com

${ }^{1}$ Nestec Ltd, Nestlé Research Centre, Vers-chez-les-Blanc, P.O. Box 44, Lausanne 26 1000, Switzerland

Full list of author information is available at the end of the article
}

mechanisms evolved by microorganisms to counteract phenolic acid toxicity is the induction of enzymes able to metabolize these compounds. Lactic acid bacteria, especially Lactobacillus plantarum (van Beek 2000), Pediococcus pentosaceus (Barthelmebs 2000) and Pseudomonas fluorescens (Barghini 1998) are able to decarboxylate $p$-coumaric acid and ferulic acid into vinylphenol, vinylguaiacol and vanillic acid. The decarboxylation is catalyzed by a hydroxycinnamate decarboxylase (HCD). This enzyme was found to be produced by different groups of microorganisms including gram negative bacteria, gram positive bacteria and yeasts. Among the gram positive bacteria only lactic acid bacteria (Rodriguez 2008a; van Beek 2000; Landete 2007) and some Bacillus species (Torres y Torres 2001; Degrassi 1995; Cavin 1998; Edlin 1998) were identified to display HCD activity. This enzymatic activity might be constitutive or induced when the microorganisms are exposed to exogenous chemicals (Hashidoko 2001). The constitutive expression of HCDs has been reported in yeasts and some gram negative bacteria. The yeasts, Brettanomyces anomalus and B. bruxellensis, commonly found in wine, are responsible for the production of flavoring compounds such as 4-vinylphenol, 4- 


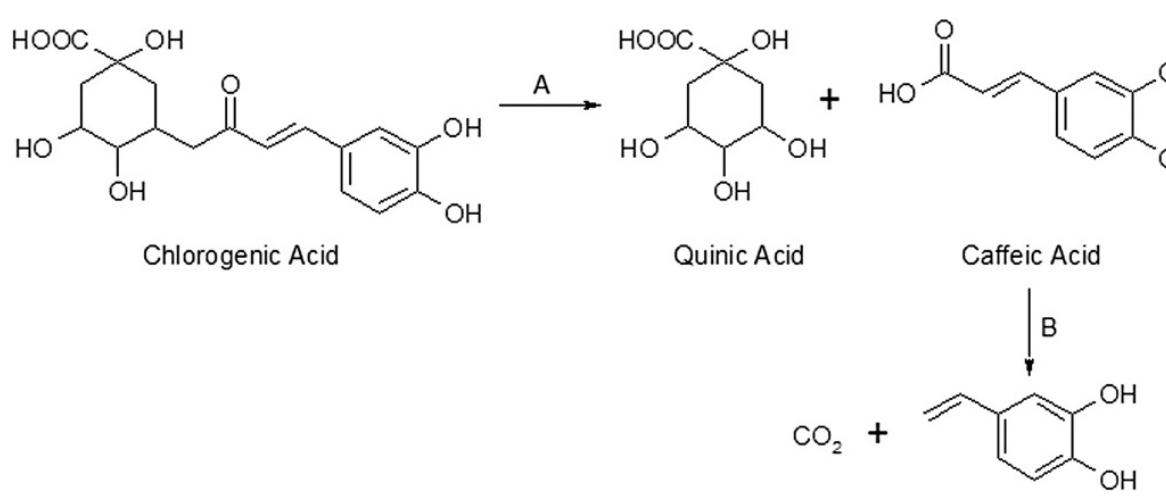

Figure 1 Biotransformation of chlorogenic acids into 4-vinylcatechol by L. johnsonii. (A) cinnamoyl esterase activity, (B) hydroxycinnamate decarboxylase activity.

vinylguaiacol, 4-ethylphenol and 4-ethylguaiacol (Edlin 1998; Godoy 2008; Morata 2013) which are the catalytic products of cinnamic acids mediated by HCD. 4-Vinyl derivatives are considered to contribute to the smoky aroma of cured meat products (Guillén 1998). 4-VG and 4-VP have been approved as flavoring agents by regulatory agencies (Joint Expert Committee on Food Additives (JECFA) 2001). 4-Vinyl derivatives have also been reported as potent antioxidants (Terpinc 2011). The HCD activity has been reported in Lactobacillus species (Rodriguez 2008 a, 2008b; van Beek 2000; Landete 2007) but not yet in L. johnsonii. In a previous study we demonstrated the ability of $L$. johnsonii to hydrolyze rosmarinic acid into caffeic and 3,4dihydroxyphenyllactic acids (Bel-Rhlid 2009). In the present study, we investigated the in vitro incubation of green coffee extract with $L$. johnsonii to hydrolyze chlorogenic acids into corresponding hydroxycinnamic acids. These phenolic compounds could be then transformed into corresponding vinylphenols by decarboxylase activity.

\section{Materials and methods}

\section{Chemicals}

Caffeic acid, $p$-coumaric acid, 5-caffeoylquinic acid (5CQA) and 4-vinylguaiacol (4-VG) were purchased from Sigma-Aldrich (Switzerland). Dimethyl sulfoxide (DMSO), sodium phosphate $\left(\mathrm{NaPO}_{4}\right)$, acetonitrile (HPLC grade), tri-fluoro acetic acid (TFA) and methanol were purchased from Merck (Germany). Green coffee extract (GCE) was produced from $100 \%$ whole beans Robusta coffee (decaffeinated) by counter-current gradient extraction at 110$180^{\circ} \mathrm{C}$. The extract was concentrated by evaporation to a solid content of $50 \%$ and then spray-dried. GCE was stored as a powder at $-20^{\circ} \mathrm{C}$ until further use.

\section{Microorganism}

Spray-dried culture powder containing Lactobacillus johnsonii (NCC 533, $1.19 \mathrm{E} 10 \mathrm{cfu} / \mathrm{g}$ ) was kindly provided by Nestlé Culture Collection.
Incubation of green coffee extract (GCE) with L. johnsonii NCC 533

GCE (30 mg) and a spray-dried preparation of L. johnsonii $(10 \mathrm{mg}, 1.19 \mathrm{E} 10 \mathrm{cfu} / \mathrm{g})$ were suspended in $1 \mathrm{ml}$ phosphate buffer (10 mM, pH 7.0) and incubated at $37^{\circ} \mathrm{C}$ (Eppendorf, thermomixer) for $24 \mathrm{~h}$. Samples were withdrawn at different reaction times, centrifuged $\left(14000 \mathrm{~g}, 10 \mathrm{~min}, 4^{\circ} \mathrm{C}\right)$, filtered $(0.22 \mu \mathrm{m})$, and analyzed by HPLC. The influence of temperature, $\mathrm{pH}$, and oxygen on the reaction rate and yield were studied. For all experiments, a reaction control was run in parallel under the same conditions but without bacteria. No formation of caffeic acid and 4-vinylcatechol was observed in all reaction controls.

Incubation of $p$-coumaric and caffeic acids with $L$. johnsonii $p$-Coumaric acid $(3 \mu \mathrm{mol} / \mathrm{ml})$ was dissolved in phosphate buffer $(50 \mathrm{mM}, \mathrm{pH}$ 7.0). To this suspension, a spray-dried preparation of L. johnsonii $(10 \mathrm{mg} / \mathrm{ml}, 1.19$ E10 cfu/g) was added and the mixture incubated at $37^{\circ} \mathrm{C}$ for $24 \mathrm{~h}$. Bacteria cells were then harvested by centrifugation, washed with phosphate buffer $(10 \mathrm{mM}, \mathrm{pH} 7.0)$ and suspended in a solution of caffeic acid $(2.75 \mu \mathrm{mol} / \mathrm{ml}$, phosphate buffer $50 \mathrm{mM}, \mathrm{pH}$ 7.0). The reaction mixture was incubated at $37^{\circ} \mathrm{C}$ for $24 \mathrm{~h}$. Samples were withdrawn at different reaction times, centrifuged $(14000 \mathrm{~g}, 10 \mathrm{~min}$, $\left.4^{\circ} \mathrm{C}\right)$, filtered $(0.22 \mu \mathrm{m})$, and analyzed by HPLC for the quantification of CA and 4-VC. Similarly, L. johnsonii $(10 \mathrm{mg} / \mathrm{ml}, 1.19 \mathrm{E} 10 \mathrm{cfu} / \mathrm{g})$ was incubated with CA $(2.75 \mu \mathrm{mol} / \mathrm{ml}$, phosphate buffer $50 \mathrm{mM})$ at different $\mathrm{pHs}$ (5.0, 6.0 and 7.0) for $24 \mathrm{~h}$ at $37^{\circ} \mathrm{C}$. Samples were withdrawn at different reaction times, centrifuged $(14000 \mathrm{~g}$, $\left.10 \mathrm{~min}, 4^{\circ} \mathrm{C}\right)$, filtered $(0.22 \mu \mathrm{m})$, and analyzed by HPLC.

\section{Liquid chromatography-diode array detection (HPLC-DAD) and liquid} Chromatography-mass spectrometry (LC-MS)

Analyses of kinetic study samples were performed on an Agilent-1200 system equipped with a Nucleosil- 
C18-100-5CC column $(4.6 \times 250 \mathrm{~mm}, 5 \mu \mathrm{m})$ (MachereyNagel, Switzerland) and DAD detector. As 4-VC was not commercially available, 4-vinylguaiacol (4-VG) was used as calibrant without correction factor. Stock solutions were prepared by dissolving separately 5-CQA (20 mg), CA (20 mg) and 4-VG (20 mg) in $10 \mathrm{ml}$ methanol-water solution (70:30, v/v). 250, 500, 1000, 3000 and $5000 \mu \mathrm{l}$ of these stock solutions were then diluted in $10 \mathrm{ml}$ methanol-water (70:30, v/v) and used as standards for calibration curve. Coffee samples were diluted to $1 \%$ solid content and filtered over $0.45 \mu \mathrm{m}$ pore size syringe filters (Millipore). The column was equilibrated with $50 \%$ water containing $0.1 \%$ TFA (solvent A) and 50\% acetonitrile (solvent $\mathrm{B}$ ) at a constant flow rate of $1 \mathrm{ml} /$ min and column temperature of $40^{\circ} \mathrm{C}$. After injection $(10 \mu \mathrm{l})$, the gradient elution program was as follows: 0$16 \mathrm{~min} 12 \% \mathrm{~B}$ isocratic, $16-16.5 \mathrm{~min} 14.9 \% \mathrm{~B}, 16.5-$ 25 min $25 \%$ B, 25-30 min 25\% B, 30-32 min 100\% B and post time $5 \mathrm{~min}$ with $12 \% \mathrm{~B}$. Chlorogenic acids; 3-CQA $(\mathrm{rt}=4.55 \mathrm{~min}), 4-\mathrm{CQA} \quad(\mathrm{rt}=7.20 \mathrm{~min}), 5-\mathrm{CQA} \quad(\mathrm{rt}=$ $7.99 \mathrm{~min})$; and $\mathrm{CA}(\mathrm{rt}=9.97 \mathrm{~min})$ were monitored at $325 \mathrm{~nm}$ while 4 -VC ( $\mathrm{rt}=22.35 \mathrm{~min}$.) was monitored at $265 \mathrm{~nm}$.

HPLC-MS was performed on an Agilent-1200 tandem ToF (G6210) system equipped with a XDB C-18 column $(4,6 \mathrm{~mm} \times 50 \mathrm{~mm}, 1.8 \mu \mathrm{m})$. The LC-TOF detector was equipped with an atmospheric pressure chemical ionization source (ESI) operated in negative mode. Experimental parameters were as follows: charging voltage, $2000 \mathrm{~V}$; capillary voltage, $5000 \mathrm{~V}$; vaporizer temperature, $200^{\circ} \mathrm{C}$; nebulizer pressure, 50 psig; drying gas flow, $13.0 \mathrm{~L} / \mathrm{min}$; gas temperature, $350^{\circ} \mathrm{C}$; octopole $\mathrm{DC}$, $35.50 \mathrm{~V}$; fragmentor, $225 \mathrm{~V}$; octopole RFV, $250 \mathrm{~V}$; and skimmer, $60 \mathrm{~V}$. The eluents were $0.1 \%$ formic acid in water (A) and 100\% methanol (B). The injection volume was $10 \mu \mathrm{l}$ and a linear gradient from $5 \%$ to $67 \% \mathrm{~B}$ in 8 min was used for the separation. 4-VC was detected at a retention time of $3.95 \mathrm{~min}$.

Purification of 4-VC was performed on a Waters preparative HPLC system comprising 2767 sample manager module, 2525 binary gradient pump module and 2996 photodiode array detector module. The separation was achieved on an Xterra preparative column RP18 OBD $5 \mu \mathrm{m}, 19 \times 150 \mathrm{~mm}$ and guard column RP18 $5 \mu \mathrm{m}, 19 \times$ $10 \mathrm{~mm}$. The solvents used were water containing $0.1 \% \mathrm{v} / \mathrm{v}$ of TFA (A) and acetonitrile $100 \%$ (B). $1 \mathrm{ml}$ of GCE treated with $L$. johnsonii was injected. The following gradient and flow rate conditions were applied: $0 \mathrm{~min} 15 \%$ B $5 \mathrm{ml} / \mathrm{min}$., $2 \mathrm{~min} 15 \% \mathrm{~B} 20 \mathrm{ml} / \mathrm{min}$., $12 \mathrm{~min} 25 \%$ B $20 \mathrm{ml} / \mathrm{min}$., $13 \mathrm{~min} 100 \%$ B $20 \mathrm{ml} / \mathrm{min}$., then wash with $100 \% \mathrm{~B}$ for $5 \mathrm{~min}$ and re-equilibrate at initial conditions for $2 \mathrm{~min}$. Fractions eluting between 8.5-9.2 min were collected, concentrated to $10 \mathrm{ml}$ under slight vacuum (200 mbar) and further evaporated to dryness under high vacuum at a temperature between $60^{\circ} \mathrm{C}$ and $0^{\circ} \mathrm{C}$.

\section{Nuclear magnetic resonance (NMR)}

NMR data were acquired on a Bruker AVANCE DPX360 NMR spectrometer operating at a frequency of $360.13 \mathrm{MHz}$ for $1 \mathrm{H}$ and $90.55 \mathrm{MHz}$ for $13 \mathrm{C}$ at $25^{\circ} \mathrm{C}$. Samples were prepared in $\mathrm{d}_{6}$-dimethyl sulfoxide (DMSO-d 6 , 99.9 atom \% D; Sigma-Aldrich). Chemical shifts were measured in parts per million ( $\mathrm{ppm})$ values relative to that of the solvent (residual DMSO [H 2.50; C 39.5]). 1D NMR spectra were recorded (7183.91 Hz) with 256 or 512 data points zero filled to 256 or 512 . $13 \mathrm{C}$ spectra were acquired with $2 \mathrm{~K}$ data points zero filled to $16 \mathrm{~K} .13 \mathrm{C}$ spectra were recorded by using the DEPT pulse with proton pulse at 135 degrees. The spectra were measured under proton decoupling during acquisition and with DEPT polarization transfer pulse sequence. Homonuclear $1 \mathrm{H}-1 \mathrm{H}$ correlation (COSY) was achieved with $1 \mathrm{H}$ spectral width between 3033.98 and $7183.91 \mathrm{~Hz}$ and using eCOSY sequence with gradient pulses for selection. The data were recorded in $2 \mathrm{~K}$ data points in $\mathrm{t} 2$ and 128 data points in $\mathrm{t} 1$. Data were treated using TopSpin (version 1.3, Bruker $\mathrm{GmbH}$ ).

$\delta_{\mathrm{H}}\left(360 \mathrm{MHz} ; \mathrm{DMSO}-\mathrm{d}_{6}\right) 4.97(1 \mathrm{H}, \mathrm{dd}, J 1.2$ and 10.9, $\left.=\mathrm{CH}_{2}\right), 5.45(1 \mathrm{H}, \mathrm{dd}, J 1.2$ and $17.5,=\mathrm{CH}), 6.50$ $\left(1 \mathrm{H}, \mathrm{dd}, J 10.9\right.$ and 17.5, $\left.=\mathrm{CH}_{2}\right)$, 6.6-6.7 (2 H, m, ArH), $6.81(1 \mathrm{H}, \mathrm{d}, \mathrm{ArH}), 8.92\left(2 \mathrm{H}\right.$, br s, OH); $\delta_{\mathrm{C}}(90 \mathrm{MHz}$; DMSO- $\left.\mathrm{d}_{6}\right) 110.5,113.2,115.7,118.2,129.0,136.9$, 145.3, 145.8 .

\section{Results}

Treatment of green coffee extract (GCE) with L. Johnsonii NCC 533

GCE was incubated with $L$. johnsonii for $24 \mathrm{~h}$ and samples were withdrawn after 0,16 and $24 \mathrm{~h}$ of reaction time and analyzed by HPLC. As shown in Figure 2, during the first $16 \mathrm{~h}$ of incubation, the concentration of chlorogenic acids decreased and that of CA increased to reach a maximum of $10 \mu \mathrm{mol} / \mathrm{ml}$. After $24 \mathrm{~h}$ of reaction time, the concentration of CA decreased and 4-VC was produced $(7.5 \mu \mathrm{mol} / \mathrm{ml})$. These results suggest that chlorogenic acids were hydrolyzed by $L$. johnsonii esterase into quinic and caffeic acids and then CA was transformed into 4-VC by a hydroxycinnamic acid decarboxylase (HCD) (Figure 1). No formation of CA and 4-VC was observed in the reaction controls.

\section{Purification and characterisation of 4-VC}

4-VC was purified by preparative RP-HPLC. Upon concentration it tended to undergo quick polymerization. Therefore the final evaporation to dryness was conducted under low temperature and high vacuum. Its chemical structure was elucidated by analytical LC- 


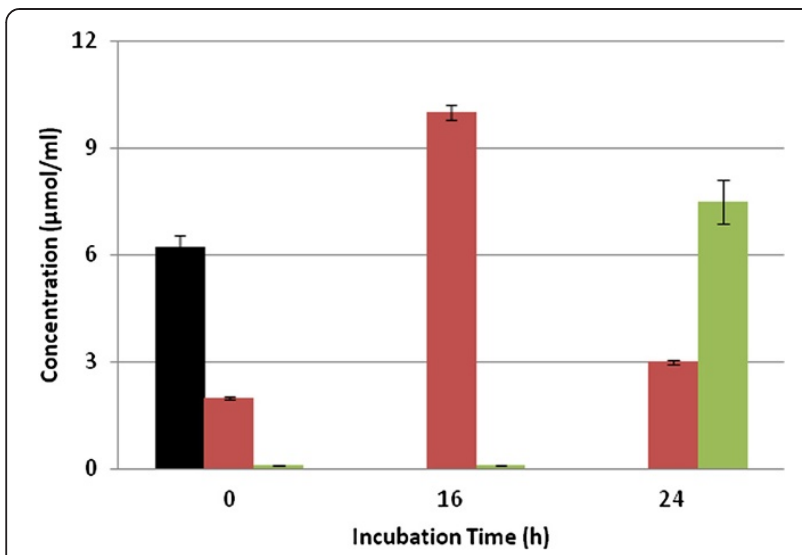

Figure 2 Bionconversion of chlorogenic acid (5-CQA) ( $\square$ ) and formation of caffeic acid (red square symbol) and 4vinylcatechol (light green square symbol) from green coffee extract by $L$. johnsonii at $37^{\circ} \mathrm{C}$. Values are mean of three different experiments.
ToF-MS and NMR (1H, 13C, COSY, DEPT). The molecular mass of 135.061 was measured in the negative mode which was a good match with the mono-isotopic mass of 136.052, expected for 4-VC. $1 \mathrm{H}$ and 13C-NMR data were identical to those described in literature (Nomura 2005).

\section{Reaction kinetics}

The kinetic behavior of the formation of CA and 4-VC was studied. Reactions were performed in phosphate buffer $(10 \mathrm{mM}, \mathrm{pH} 7.0)$ at $37^{\circ} \mathrm{C}$. As shown in Figure 3, the concentration of CA increased during the first $16 \mathrm{~h}$ of incubation and the $\mathrm{pH}$ decreased from 7.0 to 6.0. After $16 \mathrm{~h}$ of reaction time, 4-VC started to be produced to reach the concentration of $10.4 \mu \mathrm{mol} / \mathrm{ml}$ after $48 \mathrm{~h}$.

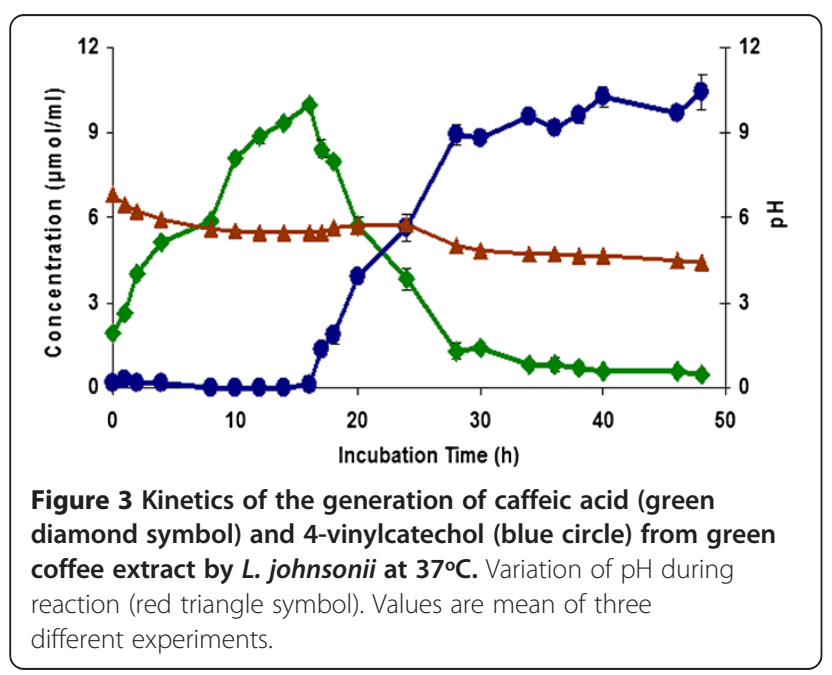

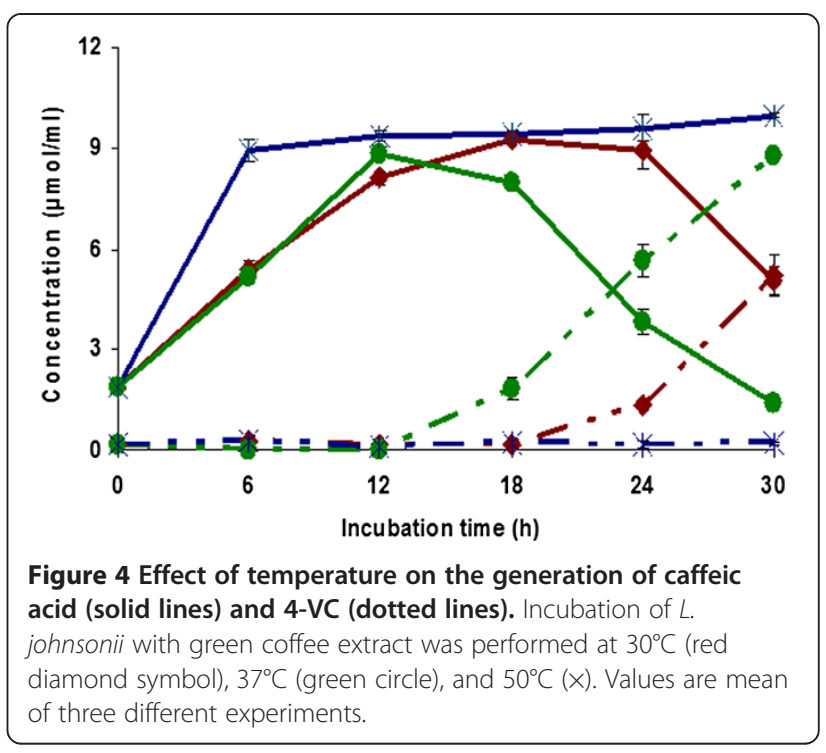

Effect of temperature on the formation of CA and 4-VC The effect of temperature on the formation of CA and 4-VC was studied. Figure 4 shows that the formation of $\mathrm{CA}$ and $4-\mathrm{VC}$ was influenced by the temperature. For the $\mathrm{CA}$, no significant difference was observed when the reaction was performed at $30^{\circ} \mathrm{C}$ or $37^{\circ} \mathrm{C}$, whereas at $50^{\circ} \mathrm{C}$ the reaction rate was much faster. Indeed, at $50^{\circ} \mathrm{C}$ a concentration of $8.9 \mu \mathrm{mol} / \mathrm{ml}$ of CA was reached after only $6 \mathrm{~h}$ of incubation as compared to $5.4 \mu \mathrm{mol} / \mathrm{ml}$ and $5.2 \mu \mathrm{mol} / \mathrm{ml}$ at $30^{\circ} \mathrm{C}$ and $37^{\circ} \mathrm{C}$, respectively. The highest concentration of $4-\mathrm{VC}(8.8 \mu \mathrm{mol} / \mathrm{ml})$ was obtained at $37^{\circ} \mathrm{C}$ and after $30 \mathrm{~h}$ of reaction time, while no $4-\mathrm{VC}$ was produced at $50^{\circ} \mathrm{C}$.

\section{Effect of $\mathrm{pH}$ on the formation of CA and 4-VC}

The influence of $\mathrm{pH}$ on the formation of $\mathrm{CA}$ and $4-\mathrm{VC}$ was studied. Figures 5 and 6 show the formation of CA

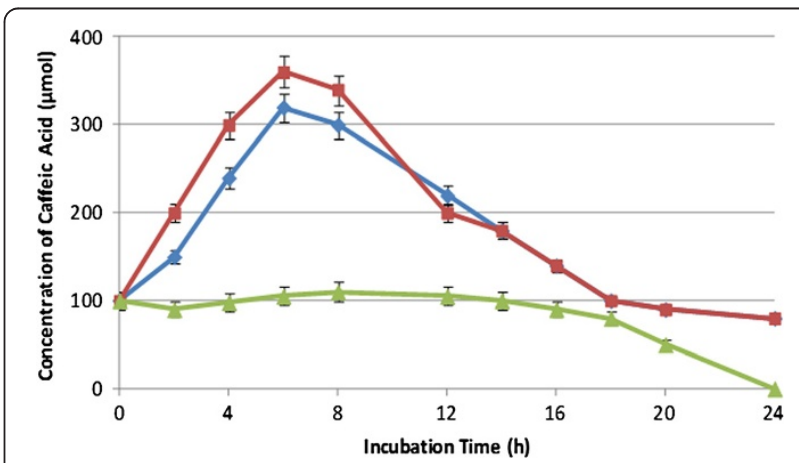

Figure 5 Effect of $\mathrm{pH}$ on the formation of caffeic acid from green coffee extract by $L$. johnsonii at $37^{\circ} \mathrm{C}$ and $\mathrm{pH} 5.0$ (blue diamond symbol), $\mathrm{pH} 6.0$ (red rectangle symbol) and pH 7.0 (light green triangle symbol). Values are mean of three different experiments. 


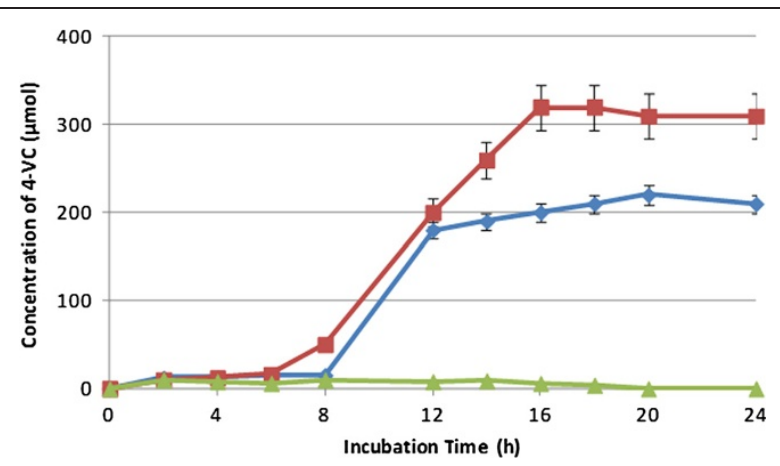

Figure 6 Effect of $\mathrm{pH}$ on the formation of 4-vinylcatechol from green coffee extract by $L$. johnsonii at $37^{\circ} \mathrm{C}$ and $\mathrm{pH} 5.0$ (blue diamond symbol), $\mathrm{pH} 6.0$ (red rectangle symbol) and $\mathrm{pH} 7.0$ (light green triangle symbol). Values are mean of three different experiments.

and 4-VC, respectively, at $\mathrm{pH}$ values of 5.0, 6.0, and 7.0. Reactions were carried out using L. johnsonii and GCE at $37^{\circ} \mathrm{C}$. Constant $\mathrm{pH}$ was adjusted by continuous titration with sodium hydroxide $(0.1 \mathrm{~N}) .4-\mathrm{VC}$ was not produced at $\mathrm{pH}$ 7.0. The maximum concentration of 4-VC was reached at $\mathrm{pH} 6.0$, while no significant difference was observed at $\mathrm{pH} 5.0$ and 6.0 for the formation of CA.

\section{Effect of anaerobic conditions on the formation of CA and 4-VC}

Figure 7 shows the influence of anaerobic conditions (nitrogen) on the generation of $\mathrm{CA}$ and 4-VC. As compared to aerobic conditions (Figure 3), anaerobic conditions slowed down the formation rate and yield of $\mathrm{CA}$ and 4 -VC. Indeed, after $26 \mathrm{~h}$ of incubation, only $4.8 \mu \mathrm{mol} / \mathrm{ml}$ of CA was formed under anaerobic conditions as compared to aerobic conditions $(8.5 \mu \mathrm{mol} / \mathrm{ml})$. Similarly, after $48 \mathrm{~h}$ of reaction time,

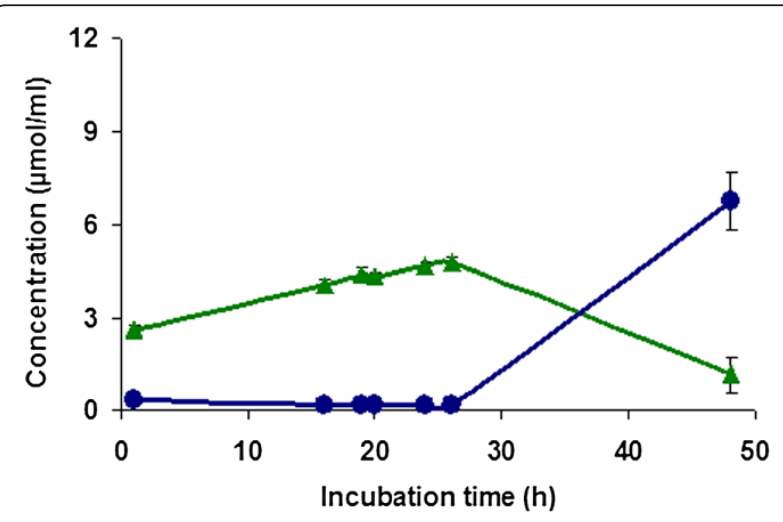

Figure 7 Formation of caffeic acid (light green triangle symbol) and 4-vinylcatechol (blue circle) from green coffee extract by L. johnsonii under anaerobic condition and at $37^{\circ} \mathrm{C}$. Initial $\mathrm{pH} 7.0$ was not controlled during the reaction. Values are mean of three different experiments. only $6.8 \mu \mathrm{mol} / \mathrm{ml}$ of $4-\mathrm{VC}$ was generated under anaerobic conditions which is much lower compared to $10.4 \mu \mathrm{mol} / \mathrm{ml}$ produced under aerobic conditions.

\section{p-coumaric and caffeic acids do not induce HCD activity in L. johnsonii}

$p$-Coumaric and caffeic acids have been reported to induce the expression of HCD in Klebsiella oxytoca JCM1665 (Hashidoko 2001) and in L. plantarum $748^{\mathrm{T}}$ (Rodriguez 2008; Cavin 1997) at a concentration of $2 \mathrm{mM}$ to $3 \mathrm{mM}$.

In this study, L. johnsonii was incubated with $p$ coumaric acid at a concentration of $3 \mathrm{mM}$ in order to induce the HCD activity. Under these reaction conditions no 4-vinylphenol could be identified in the reaction media even after $48 \mathrm{~h}$ of reaction time. Pure caffeic acid was also not transformed into 4-VC under the same reaction conditions. The activity test was performed at three different $\mathrm{pHs}$ and in all trials caffeic acid was not transformed by $L$. johnsonii and no 4 -VC could be identified in the reaction mixture (data not shown).

\section{Discussion}

Chlorogenenic acids (CQA) are found in wide range of vegetables and fruits and are particularly abundant in green coffee (6 - 10\% dry basis) (Clarke 1987). Roasting of green coffee beans reduces the amount of chlorogenic acids (2.5-4.0\%) (Debry 1994) and hypothetical chemical degradation pathway has been proposed (Franck 2007; Müller 2007). On the other hand, intestinal microorganisms (Couteau 2001; Monteiro 2007) and other lactic acid bacteria (Guglielmetti 2008) were shown to be able to transform chlorogenic acids into caffeic and quinic acids by cinnamoyl esterase. Several other studies reported on the decarboxylation of hydroxycinnamic acids (e.g. caffeic acid, ferulic acid) into vinyl phenols by bacteria and yeasts (Plumb 1999; Huang 1994; Hashidoko 2001; Rodriguez 2008; Curiel 2010). However, to our knowledge, this is the first study reporting on two step, one pot bioconversion of caffeoyl quinic acids into $4-\mathrm{VC}$ by the same microorganism (Figure 1). Our study reveals that L. johnsonii NCC 533 exhibits a chlorogenate esterase and a hydroxycinnamate decarboxylase like activities when incubated with green coffee extract for $24 \mathrm{~h}$ at $37^{\circ} \mathrm{C}$. The chlorogenate esterase from $L$. johnsonii was already identified, cloned, and characterized (Bel-Rhlid 2009; Kim 2009). This enzyme showed high affinity and catalytic efficiency toward aromatic compounds such as chlorogenic acids. HCD has never been reported in $L$. johnsonii NCC 533. To explore both enzymatic activities synergistically, L. johnsonii was used as whole 
cell and it was incubated with GCE in a one pot reaction system. The formation kinetics of $\mathrm{CA}$ and 4$\mathrm{VC}$ were studied under different reaction conditions. The first reaction, hydrolysis of chlorogenic acids into CA, started quickly, and the highest concentration of CA was generated after $16 \mathrm{~h}$ of incubation. After this level of CA was reached, the second reaction, decarboxylation of CA, was started, and after $28 \mathrm{~h}$ of reaction time a plateau was reached with maximum concentration of 4-VC. In the literature, the most frequently observed metabolic pathway of CA is by decarboxylation (Landete 2007; Cavin 1997; de las Rivas 2009) and further reduction to yield 4-ethylcatechol (Peppercorn 1971; Landete 2007). Alternatively, CA can be reduced to dihydrocaffeic acid which is then dehydroxylated into $m$ hydroxyphenylpropionic acid. In our study, neither 4ethylcatechol nor dihydrocaffeic acid were identified in the reaction mixture. Similar results have been reported for Lactobacillus brevis strains (Curiel 2010).

HCD activity was reported to be sensitive to the effects of temperature and $\mathrm{pH}$ and this sensitivity depends on the type of microorganisms (Degrassi 1995; Cavin 1998; Benito 2009). In this study, we observed that both reactions, A and B (Figure 1), were markedly influenced by the temperature and $\mathrm{pH}$. Higher temperatures accelerated the rate of formation of CA. At $50^{\circ} \mathrm{C}$, reaction A was completed within $6 \mathrm{~h}$, whereas reaction $\mathrm{B}$ was completely inhibited (Figure 4). The optimum temperature and $\mathrm{pH}$ for $\mathrm{HCD}$ activity was found to be $37^{\circ} \mathrm{C}$ and 6.0, respectively. Similar observations have been made for $p$-coumarate decarboxylase from Bacillus pumilus (Degrassi 1995) where optimum temperature and $\mathrm{pH}$ were $37^{\circ} \mathrm{C}$, and 5.5 , respectively. The decarboxylase activity was lost above $42^{\circ} \mathrm{C}$ and $100 \%$ activity was exhibited at a $\mathrm{pH}$ range of 5.0 to 6.0. A broad range of temperature and $\mathrm{pH}$ has been reported for $p$-coumarate decarboxylase from Bacillus subtilis. High activity was observed in temperature range of $30^{\circ} \mathrm{C}$ to $55^{\circ} \mathrm{C}$ and $\mathrm{pH}$ range of 4.0 to 6.0 .

Although the anaerobic degradation of aromatic compounds is not well explored, few studies have shown that decarboxylation reaction may play important initiating roles in the usage of aromatic compounds under anaerobic conditions (Krumholz 1986; Hsu 1990). The biotransformation of CQA into 4 -VC by $L$. johnsonii was successfully performed under aerobic and anaerobic conditions. Similar results were observed for Bacillus pumilus (Degrassi 1995), where the study demonstrated that $p$-coumarate decarboxylase activity was not oxygen dependent. In the case of $L$. johnsonii, the biotransformation rate of CQA into 4-VC was delayed by anaerobic conditions and the final concentration of 4-VC was only $6.75 \mu \mathrm{mol} / \mathrm{ml}$ as compared to $9 \mu \mathrm{mol} / \mathrm{ml}$ obtained under aerobic conditions. In both cases, CA was completely consumed. This suggests that the decarboxylation of CA stopped due to substrate limitation and not to the influence of oxygen. The HCD activity in our studied conditions relies on the catalytic activity of chlorogenate esterase as well. As a result, less CA was produced in the mixture under anaerobic conditions as compared to aerobic conditions.

$p$-Coumaric and caffeic acids have already been shown to induce the expression of HCD at a concentration of $2 \mathrm{mM}$ to $3 \mathrm{mM}$ in Klebsiella oxytoca JCM1665 (Hashidoko 2001) and in L. plantarum $748^{\mathrm{T}}$ (Rodriguez 2008; Cavin 1997). These chemical inducers were also substrates for HCD activity. To investigate the induction of $\mathrm{HCD}$ activity in $L$. johnsonii NCC 533, the bacterium was preincubated with $p$ coumaric and caffeic acids separately and the HCD activity was tested with CA as substrate. The cells did not transform CA at all tested reaction conditions. This leaves the assumption that GCE contains some unknown substance which might regulate the expression of HCD in L. johnsonii. Moreover, the cell count of La1 decreased by 10 -fold during the first $16 \mathrm{~h}$ of reaction and reached a little higher account than the initial one after $24 \mathrm{~h}$. The slow dying off of cells might be due to the high concentration of $\mathrm{CA}$ reached after $16 \mathrm{~h}$ of reaction time. At this point, the cells commenced detoxifying the toxic effect of $\mathrm{CA}$ by transforming this compound into $4-\mathrm{VC}$ and started again to grow slowly. The same observation was reported in $L$. plantarum and $P$. pentosaceus (Barthelmebs 2001). However, further experimental work will be required to confirm these hypotheses and to understand the induction and/or activation mechanism of HCD in $L$. johnsonii. The purification and characterization of this enzyme has to be also explored in the future.

In summary, in this study we showed the ability of L. johnsonii to transform caffeoylquinic acid (5-CQA) from green coffee extract into 4-VC. The results obtained indicate that two enzymes, an esterase and a hydroxycinnamic decarboxylase, were involved in this biotransformation. Thus, the enzymatic potential of certain lactobacilli might be explored to produce flavor compounds or to enhance bioactivity of plant phenolic compounds.

\section{Competing interests}

The authors declare that they have no competing interests.

\section{Acknowledgements}

The authors are grateful to Nicole Page-Zoerkler and Olivier Mauroux for their technical assistant. We thank David Pridmore and Kimo Makkinen for critical reading of this manuscript.

\section{Author details}

${ }^{1}$ Nestec Ltd, Nestlé Research Centre, Vers-chez-les-Blanc, P.O. Box 44, Lausanne 26 1000, Switzerland. ${ }^{2}$ Rowett Institute of Nutrition and Health Gut, 
Health/Microbial Biochemistry, University of Aberdeen, Greenburn Road, Bucksburn, Aberdeen AB21 9SB, Scotland. ${ }^{3}$ Institute of Food Science and Biotechnology, Faculty of Natural Sciences, University of Hohenheim (Stuttgart), Garbenstr. 25, Stuttgart D-70593, Germany.

Received: 8 May 2013 Accepted: 10 May 2013 Published: 21 May 2013

\section{References}

Barghini P, Montebove F, Ruzzi M, Schiesser A (1998) Optimal conditions for bioconversion of ferulic acid into vanillic acid by Pseudomonas fluorescens BF13 cells. Appl Microbiol Biotechnol 49:309-314

Barthelmebs L, Lecomte B, Divies C, Cavin JF (2000) Induced metabolism of phenolic acids in Pediococcus pentosaceus is encoded by an autoregulated operon which involves a new class of negative transcriptional regulator. J Bacteriol 182:6724-6731

Barthelmebs L, Divies C, Cavin JF (2001) Molecular characterization of the phenolic acid metabolism in the lactic acid bacteria Lactobacillus plantarum. Lait 81:161-171

Bel-Rhlid R, Crespy V, Page-Zoerkler N, Nagy K, Raab T, Hansen CE (2009) Hydrolysis of rosmarinic acid from rosemary extract with esterases and Lactobacillus johnsonii in-vitro and in a gastro-intestinal model. J Agric Food Chem 57:7700-7705

Benito S, Palomero F, Morata A, Calderón F, Suá rez-Lepe JA (2009) A method for estimating Dekkera/Brettanomyces polulations in wines. J Appl Microbiol 106:1743-1751

Cavin JF, Barthelmebs L, Guzzo J, van Beeumen J, Samyn B, Travers JF, Divies C (1997) Purification and characterization of an inducible $p$-coumaric acid decarboxylase from Lactobacillus plantarum. FEMS Microbiol Lett 147:291-295

Cavin JF, Dartois V, Divies C (1998) Gene cloning, transcriptional analysis, purification, and characterization of phenolic acid decarboxylase from Bacillus subtilis. Appl Environ Microbiol 64:1466-1471

Clarke RJ (1987) Coffee technology. In: Herschdoefer SH (ed) Quality control in the food industry, 2nd edn. Academic, London, pp 161-191

Couteau D, Mccartney AL, Gibson GR, Williamson G, Faulds CB (2001) Isolation and characterization of human colonic bacteria able to hydrolyze chlorogenic acid. J Appl Microbiol 90:873-881

Curiel JA, Rodriguez H, Landete JM, de las Rives B, Munoz R (2010) Ability of Lactobacillus brevis strains to degrade food phenolic acids. Food Chem 120:225-229

De Las Rivas B, Rodriguez H, Curiel JA, Landete JM, Munoz R (2009) Molecular screening of wine lactic acid bacteria degrading hydroxycinnamic acids. J Agric Food Chem 57:490-494

Debry G (1994) Coffee and health. John Libbey Eurotext, Paris

Degrassi G, de Laureto PP, Bruschi CV (1995) Purification and characterization of ferulate and $p$-coumarate decarboxylase from Bacillus pumilus. Appl Environ Microbiol 61:326-332

Edlin DAN, Narbad A, Gasson MJ, Dickinson JR, Lloyd D (1998) Purification and characterization of hydroxycinnamate decarboxylase from Brettanomyces anomalus. Enzyme Microb Technol 22:232-239

Franck O, Blumberg S, Kunert C, Zehentbauer G, Hofmann T (2007) Structure determination and sensory analysis of bitter-tasting 4-vinylcatechol oligomers and their identification in roasted coffee by means of LC-MS/MS. J Agric Food Chem 55:1945-1954

Godoy L, Martinez C, Carrasco N, Ganga MA (2008) Purification and characterization of a $p$-courmarate decarboxylase and a vinylphenol reductase from Brettanomyces bruxellensis. Int J Food Microbiol 127:6-11

Guglielmetti S, De Noni I, Caracciolo F, Molinari F, Parini C, Mora D (2008) Bacterial cinnamoyl esterase activity screening for the production of a novel functional food product. Appl Environ Microbiol 74:1284-1288

Guillén MD, lbargoitia ML (1998) New components with potential antioxidant and organoleptic properties, detected for the first time in liquid smoke flavouring preparations. J Agric Food Chem 46:1276-1285

Hashidoko Y, Tanaka T, Tahara S (2001) Induction of 4-hydroxycinnamate decarboxylase in Klebsiella oxytoca cells exposed to substrates and nonsubstrate 4-hydroxycinnamate analogs. Biosci Biotechnol Biochem 65:2604-2612
Hsu T, Lux MF, Drake HL (1990) Expression of an aromatic-dependent decarboxylase which provides growth-essential $\mathrm{CO}_{2}$ equivalents for the acetogenic (Wood) pathway of Clostridium thermoaceticum. J Bacteriol 172:5901-5907

Huang Z, Dostal L, Rosazza JPN (1994) Purification and characterization of a ferulic acid decarboxylase from Pseudomonas fluorescens. J Bacterio 176:5912-5918

Joint Expert Committee on Food Additives (2001) Evaluation of certain food additives and contaminants, 55th report of the joint WHO/FAO expert committee on food additives. WHO Technical Report series 901. World Health Organization, Geneve, Switzerland

Kim KL, Lorca GL, Gonzalez CF (2009) Biochemical properties of two cinnamoyl esterases purified from a Lactobacillus johnsonii strain isolated from stool samples of diabetes-resistant rats. Appl Environ Microbiol 75:5018-5024

Krumholz LR, Bryant MP (1986) Eubacterium oxidoreducens sp. nov. requiring $\mathrm{H}_{2}$ or formate to degrade gallate pyrogallol, phloroglucinol and quercetin. Arch Microbiol 144:8-14

Landete JM, Rodriguez H, de Las Rivas B, Munoz R (2007) High-added -value antioxidants obtained from the degradation of wine phenolics by Lactobacillus plantarum. J Food Prot 70:2670-2675

Monteiro A, Farah A, Perrone D, Trugo LC, Donangelo C (2007) Chlorogenic acid compounds from coffee are differentially absorbed and metabolized in humans. J Nutr 137:2196-2201

Morata A, Vejarano R, Ridolfi G, Benito S, Palomero F, Uthurry C, Tesfaye W, Gonzáles C, Suárez-Lepe JA (2013) Reduction of 4-ethylphenol production in red wines using HCDC + -yeasts and cinnamyl esterases. Enzyme Microb Technol 52:99-104

Müller C, Hofmann T (2007) Quantitative studies on the formation of phenol/2-furfurylthiol conjugates in coffee beverages toward the understanding of the molecular mechanisms of coffee aroma staling. J Agric Food Chem 55:4095-4102

Nomura E, Hosoda A, Mori H, Taniguchi H (2005) Rapid base-catalyzed decarboxylation and amide-forming reaction of substituted cinnamic acids via microwave heating. Green Chem 7:863-866

Osborn AM, Bruce KD, Strike P, Ritchie DA (1997) Distribution, diversity and evolution of the bacterial mercury resistance (mer) operon. FEMS Microbiol Rev 19:239-262

Overhage J, Prieffert H, Steinbuechel A (1999) Biochemical and genetic analyses of ferulic acid catabolism in Pseudomonas sp. strain HR199. Appl Environ Microbiol 65:4837-4847

Peppercorn MA, Goldman P (1971) Caffeic acid metabolism by bacteria of the human gastrointestinal tract. J Bacteriol 108:996-1000

Plumb G, Garcia-Conesa MT, Kroon P, Rhodes M, Saxon R, Williamson G (1999) Metabolism of chlorogenic acid by human plasma, liver, intestine and gut microflora. J Sci Food Agric 79:390-392

Rodriguez H, Landete JM, de las Rivas B, Munoz R (2008a) Metabolism of food phenolic acids by Lactobacillus plantarum CECT $748^{\top}$. Food Chem 107:1393-1398

Rodriguez $\mathrm{H}$, Landete JM, Curiel JA, de las Rivas B, Mancheno JM, Munoz $R$ (2008b) Characterization of the p-coumaric acid decarboxylase from Lactobacillus plantarum CECT 748 ${ }^{\top}$. J Agric Food Chem 56:3068-3072

Sud'ina GF, Mirzoeva OK, Pushkareva MA, Korshunova GA, Sumbatyan NV, Varfolomeev SD (1993) Caffeic acid phenethyl ester as a lipoxygenase inhibitor with antioxidant properties. FEBS Lett 329:21-24

Terpinc P, Polak T, Segatin N, Hanzlowsky A, Ulrih NP, Abramovic H (2011) Antioxidant properties of 4-vinyl derivatives of hydroxycinnamic acids. Food Chem 128:62-69

Torres y Torres JL, Rosazza JPN (2001) Microbial transformations of $p$-coumaric acid by Bacillus megaterium and Curvularia lunata.J Nat Prod 64:1408-1414

van Beek S, Priest FG (2000) Decarboxylation of substituted cinnamic acids by lactic acid bacteria isolated during malt whisky fermentation. Appl Environ Microbiol 66:5322-5328

doi:10.1186/2191-0855-3-28

Cite this article as: Bel-Rhlid et al:: Biotransformation of caffeoyl quinic acids from green coffee extracts by Lactobacillus johnsonii NCC 533 . AMB Express 2013 3:28. 